\title{
Persepsi Guru Terhadap Proses Pembelajaran Daring Pada Masa (Pandemi Covid-19) di SMP Negeri 1 Sawan
}

\author{
Ni Nyoman Ari Suryani *1, Lulup Endah Tripalupi ${ }^{2}$ \\ 1,2Program Studi Pendidikan Ekonomi \\ Universitas Pendidikan Ganesha \\ Singaraja, Indonesia
}

\section{e-mail: ninyomanarisuryani97@gmail.com¹, tripalupilulup@gmail.com²}

Riwayat Artikel Tanggal diajukan: 21 Juni 2021

Tanggal diterima : 22 November 2021

Tanggal dipublikasikan: 15 Desember 2021

Pengutipan:

Suryani, N. N. A. \& Tripalupi, L. E. (2021). Persepsi Guru Terhadap Proses

Pembelajaran Daring Pada Masa (Pandemi Covid-19) di SMP Negeri 1 Sawan. Jurnal Pendidikan Ekonomi Undiksha, 13 (2), 340-351 http://dx.doi.org/1 $\underline{0.23887 / j i p e . v 13 i}$ 2.35761

\begin{abstract}
Abstrak
Penelitian ini bertujuan untuk mengetahui persepsi guru terhadap proses pembelajaran daring pada masa (pandemi covid-19) di SMP Negeri 1 Sawan. Jenis penelitian ini yaitu penelitian deskriptif dengan pendekatan kualitatif untuk mendeskripsikan mengenai persepsi guru terhadap proses pembelajaran daring pada masa (pandemi covid-19) di SMP Negeri 1 Sawan. Penelitian ini menggunakan seluruh guru di SMP Negeri 1 Sawan sebagai populasinya dan sampel yang digunakan sebanyak 54 orang guru. Pada penelitian ini metode pengumpulan data menggunakan kuesioner dan wawancara. Teknik analisis data yang digunakan dalam penelitian ini adalah analisis deskriptif. Hasil penelitian menunjukkan bahwa persepsi guru dari aspek kognitif memperoleh skor sebesar 1.665 sehingga berada dalam kategori baik. Persepsi guru dari aspek afektif memperoleh skor sebesar 1.669 sehingga berada dalam kategori baik. Persepsi guru dari aspek konatif memperoleh skor sebesar 1.764 dan berada dalam kategori baik. Maka dapat disimpulkan bahwa persepsi guru terhadap proses pembelajaran daring pada masa (pandemi covid-19) di SMP Negeri 1 Sawan berada dalam kategori baik.
\end{abstract}

Kata Kunci: Persepsi Guru; Pembelajaran Daring; Masa Pandemi Covid-19

Keywords: Teacher Perception; Online Learning; Covid-19 Pandemic Time 


\section{PENDAHULUAN}

Indonesia saat ini sedang mengalami wabah virus corona. Virus Corona atau severe acute respiratory syndrome coronavirus 2 (SARS-CoV-2) merupakan virus yang menyerang sistem pernapasan seperti hidung, tenggorokan dan paru-paru (Handayani, 2020). Dengan adanya wabah virus corona ini semua kegiatan pembelajaran secara tatap muka belum bisa dilakukan sehingga semua siswa diharuskan untuk belajar dirumah sesuai dengan surat edaran yang dikeluarkan pemerintah pada 18 Maret 2020 segala kegiatan di dalam dan di luar ruangan di semua sektor sementara waktu ditunda demi mengurangi penyebaran virus corona terutama pada bidang pendidikan (Dewi, 2020a). Menteri Nadiem Anwar Makarim menerbitkan Surat Edaran Nomor 4 Tahun 2020 pada Satuan Pendidikan dan Nomor 36962/MPK.A/HK/2020 tentang Pelaksanaan Pendidikan dalam Masa Darurat Coronavirus Disease (COVID-19) maka kegiatan belajar dilakukan secara daring. Pembelajaran dalam jaringan atau daring pada dasarnya adalah pembelajaran yang dilaksanakan secara virtual melalui aplikasi virtual yang tersedia, meski demikian, pembelajaran secara daring harus tetap memperhatikan kompetensi yang hendak disampaikan dan diajarkan kepada siswa (Kementerian Pendidikan dan Kebudayaan Republik Indonesia, 2020). Menurut Mulyana (Setiawan, 2020) menyatakan bahwa "guru harus memahami bahwa pembelajaran merupakan suatu hal yang sangat kompleks karena melibatkan aspek pedagogis, psikologis, dan didaktis secara bersamaan". Oleh karena itu, pembelajaran daring bukan hanya pembelajaran yang memindahkan materi melalui media internet, dan guru bukan hanya sekedar memberikan tugas dan soalsoal yang akan dikirimkan melalui aplikasi sosial media (online), pembelajaran daring harus tetap dipersiapkan, dilaksanakan, serta dievaluasi (Mursalin et al., 2017).

Pembelajaran daring atau dalam jaringan adalah pembelajaran yang dilakukan tanpa melakukan tatap muka, tetapi melalui platform yang telah tersedia (Firman \& Rahayu, 2020). Pembelajaran daring atau online pertama kali dikenal dengan perkembangan pembelajaran online berbasis elektronik atau (e-learning) sebagai alternatif dalam menciptakan lingkungan belajar yang inovatif dan memberikan siswa untuk mengenal dunia teknologi (Pamungkas, 2020). Menurut Mustakim, 2020 pembelajaran daring adalah "bentuk pembelajaran yang mampu menjadikan siswa mandiri tidak bergantung pada orang lain". Pembelajaran daring merupakan pemanfaatan jaringan internet dalam proses pembelajaran yang memerlukan teknologi informasi sehingga dapat diakses dimana saja dan kapan saja (Dewi 2020). Pembelajaran daring atau e-learning merupakan pendidikan formal yang diselenggarakan oleh sekolah yang peserta didiknya dan instrukturnya (guru) berada di lokasi terpisah sehingga memerlukan sistem telekomunikasi interaktif sebagai media penghubung keduanya dan berbagai sumber daya yang diperlukan didalamnya (Setiawan, 2020). Pembelajaran daring dapat dilakukan dengan menggabungkan beberapa jenis sumber belajar seperti dokumen, gambar, video, audio dalam pembelajaran dengan menggunakan elektronik seperti komputer, laptop dan handphone (Dewi 2020) Sumber belajar tersebut dapat dimanfaatkan peserta didik dengan melihat atau membaca. Sumber belajar seperti ini yang menjadi modal utama dalam mengembangkan pembelajaran daring.

Dalam pembelajaran daring guru harus tetap menjelaskan materi yang akan dipelajari oleh peserta didik meskipun tidak secara maksimal, oleh karena itu penggunaan metode ceramah perlu diterapkan dalam pembelajaran daring. Menurut (Ahmadi, 2016) menyatakan bahwa "metode ceramah adalah metode penyampaian pelajaran atau materi dengan penuturan lisan secara langsung maupun perantara untuk mencapai indikator atau tujuan pembelajaran yang diinginkan". Setelah diberikan penjelasan materi tentu peserta didik akan lebih mudah memahami materi yang disampaikan oleh guru sehingga peserta didik mampu mengerjakan tugas yang diberikan guru. Karena dalam pembelajaran daring ini guru selalu memberikan tugas untuk mengukur pemahaman peserta didik. 
Menurut Suparti (Hasibuan, Syahputra, 2020) menyatakan bahwa "metode penugasan adalah metode pengajaran dengan pemberian tugas pada peserta didik agar melakukan kegiatan belajar untuk dapat dipertanggung jawabkan dalam rentang waktu yang telah ditentukan". Menurut Kinasih \& Sinaga, 2020 perencanaan dapat diartikan sebagai proses penyusunan bahan ajar, menggunakan media, menggunakan pendekatan dan metode pembelajaran, serta mengevaluasi dalam kurun waktu tertentu untuk mencapai tujuan pembelajaran yang telah ditetapkan. Menurut Dhaifi, 2020 perencanaan pembelajaran daring yang ideal harus mengikuti pola yang telah disebutkan yaitu (1) perencanaan dapat diartikan sebagai suatu proses menyiapkan materi pembelajaran; (2) penggunaan media, media pembelajaran merupakan alat bantu yang digunakan untuk mempermudah siswa dalam memahami materi pembelajaran; (3) penggunaan pendekatan, mencerminkan cara berpikir dan sikap seorang pendidik dalam menyelesaikan permasalahan yang ditemui ketika kegiatan pembelajaran berlangsung; (4) penggunaan metode pembelajaran, suatu proses pemberian bahan ajar secara teratur dan sistematis kepada siswa oleh guru atau pengajar; (5) mengevaluasi dalam jangka waktu tertentu, kemudian melaksanakan dalam jangka waktu tertentu untuk mencapai tujuan yang ditetapkan. Menurut Soekartiwi, 2015 terdapat tiga hal yang dapat memberikan efek terhadap pembelajaran daring yaitu (1) teknologi, jaringan harus diatur sedemikian rupa sehingga dapat dilakukannya pertukaran sinkronisasi dan asinkronisasi, siswa harus memiliki akses yang mudah (misalnya melalui akses jarak jauh) dan jaringan harus mengambil waktu paling sedikit untuk bertukar dokumen; (2) karakteristik pengajar, pengajar memiliki peran utama dalam keefektifan pembelajaran secara daring. Siswa yang hadir dalam kelas dengan instruktur atau pengajar yang memiliki sifat positif terhadap penyaluran materi dan memahami tentang teknologi akan mampu menghasilkan pembelajaran yang positif; (3) karakteristik siswa, Leidner mengungkapkan bahwa siswa yang tidak memiliki keterampilan dasar serta kedisiplinan yang tinggi akan lebih baik menggunakan pembelajaran secara konvensional, sedangkan siswa yang memiliki kedisiplinan dan kepercayaan diri akan mampu untuk melaksanakan pembelajaran secara daring.

Menurut Rusman, 2011 e-learning atau pembelajaran dalam jaringan (daring) memiliki karakteristik-karakteristik yaitu 1) Interactivity (interaktivitas) adalah tersedianya jalur komunikasi yang lebih banyak, baik secara langsung (synchronous), seperti chatting atau messenger atau tidak langsung (asynchronous) seperti forum, mailing list, dan video pembelajaran. 2) Independency (kemandirian) adalah fleksibilitas dalam aspek penyediaan waktu, tempat, pengajar, dan bahan ajar. Hal ini menyebabkan pembelajaran menjadi lebih terpusat kepada siswa (Student-Centered Learning). 3) Accesbility (aksesibilitas) adalah sumbersumber belajar menjadi lebih mudah diakses melalui pendistribusian di jaringan internet dengan akses yang lebih luas dari pada pendistribusian sumber belajar pada pembelajaran konvensional. 4) Enrichment (pengayaan) adalah kegiatan pembelajaran, presentasi materi kuliah/sekolah dan materi pelatihan sebagai pengayaan, memungkinkan penggunaan perangkat teknologi informasi seperti video streaming, simulasi dan animasi (Riyanda et al., 2020).

Pembelajaran secara daring atau online memiliki kelebihan seperti dapat diakses oleh semua kalangan masyarakat dimana saja dan kapan saja. Pembelajaran daring dapat memperoleh ilmu pendidikan yang sama pada sekolah yang berbeda, pembelajaran daring bisa dilakukan di luar kelas atau di rumah yang dapat menghemat waktu dan tenaga. Kekurangan dari pembelajaran daring adalah sulit untuk mengontrol mana siswa yang serius mengikuti pelajaran dan mana yang tidak. Dalam hal tersebut menimbulkan adanya persepsi dari para guru selama mengajar secara daring (Maskar et al., 2020).

Persepsi merupakan kecakapan untuk melihat, memahami, kemudian menafsirkan suatu stimulus sehingga merupakan sesuatu yang berarti dan menghasilkan penafsiran. Menurut Megawanti et al., 2020 persepsi adalah proses mengatur dan mengartikan 
p-ISSN : 2599-1418

e-ISSN : 2599-1426
Jurnal Pendidikan Ekonomi Undiksha

Vol. 13 No. 2 (2021) informasi sensoris untuk memberikan makna. Persepsi merupakan suatu proses yang diawali oleh proses penginderaan, yaitu merupakan proses diterimanya stimulus oleh individu melalui alat indera atau juga disebut proses sensoris (Bimo, 2010). Persepsi dari guru mencerminkan sikap atau perilaku mereka berasal dari pengamatan. Hasil pengamatan tersebut akan memunculkan sebuah persepsi dimana persepsi tersebut bisa ke arah positif atau ke arah negatif tergantung dari pengamatan setiap individunya (Wood, 2013).

Dalam persepsi individu
mengorganisasikan diterimanya, sehingga stimulus tersebut mempunyai arti bagi individu yang bersangkutan (Wood, 2013) mengemukakan faktor yang mempengaruhi persepsi yaitu 1) Objek yang dipersepi, objek menimbulkan stimulus yang mengenai alat indera atau reseptor. Stimulus dapat datang dari luar individu yang mempersepsi, tetapi juga dapat datang dari dalam diri individu yang bersangkutan yang langsung mengenai syaraf penerima yang bekerja sebagai reseptor. Namun sebagian terbesar stimulus datang dari luar individu. 2) Alat indera, syaraf, dan pusat susunan syaraf, alat indera atau reseptor merupakan alat untuk menerima stimulus. Di samping itu juga harus ada syaraf sensoris sebagai alat untuk meneruskan stimulus yang diterima reseptor ke pusat susunan syaraf, yaitu otak sebagai pusat kesadaran. Sebagai alat untuk mengadakan respons diperlukan syaraf motoris. 3) Perhatian, untuk menyadari atau untuk mengadakan persepsi diperlukan adanya perhatian, yaitu merupakan langkah pertama sebagai suatu persiapan dalam rangka mengadakan persepsi. Perhatian merupakan pemusatan atau konsentrasi dari seluruh aktivitas individu yang ditunjukkan kepada sesuatu atau sekumpulan objek.

Ketika seseorang individu melihat sebuah target dan berusaha untuk menginterpretasikan apa yang ia lihat, interpretasi itu sangat dipengaruhi oleh berbagai karakteristik pribadi dari pembuat persepsi individual tersebut. Karakteristik target yang di observasi bisa mempengaruhi apa yang diartikan. Menurut Wood, 2013 menyatakan bahwa persepsi terbagi menjadi 3 (tiga) yaitu sebagai berikut. a) komponen kognitif (pengetahuan), respons kognitif berkaitan dengan pengetahuan, keterampilan dan informasi seseorang mengenai sesuatu. Respons ini timbul apabila adanya perubahan terhadap apa yang dipahami atau dipersepsikan oleh khalayak. b) komponen afektif (sikap), respons afektif berhubungan dengan perasaan, sikap dan penilaian seseorang terhadap sesuatu. Respons ini timbul apabila ada perubahan pada apa yang disenangi khalayak terhadap sesuatu. C) komponen konatif (tindakan), respons konatif yang berhubungan dengan perilaku nyata, meliputi tindakan, kegiatan, atau kebiasaan berperilaku. Dengan kata lain respons ini menunjukkan intensitas sikap yaitu kecenderungan bertindak atau berperilaku seseorang terhadap objek (Anggianita, 2020).

SMP Negeri 1 Sawan merupakan Sekolah Menengah Pertama (SMP) yang beralamat di Desa Sawan, Kecamatan Sawan, Kabupaten Buleleng. Berdasarkan hasil wawancara dengan guru di SMP Negeri 1 Sawan beliau mengungkapkan bahwa dengan situasi pandemi covid saat ini guru turut merasakan dampaknya, guru mengalami masalah dalam mengajar secara daring, yaitu kurang optimalnya penyampaian materi pembelajaran yang disampaikan untuk peserta didik, sehingga pembelajaran dirasa kurang bermakna bagi peserta didik. Dalam penyampaian materi metode yang digunakan guru juga terbatas, mengingat sulitnya mendapatkan kuota baik orang tua, peserta didik maupun guru, pemberian tugas untuk siswa hanya dilakukan dalam grup di aplikasi yaitu WhatsApp. Dalam pelaksanaan pembelajaran daring guru menganggap respons yang diharapkan tidak pasti. Selain itu guru harus memikirkan strategi bagaimana caranya supaya peserta didik bisa keluar dari zona kebosanan mereka. Dalam situasi saat ini peran guru harus kreatif dalam menciptakan pembelajaran daring. Kemudian kendala berikutnya, yaitu ketika melaksanakan teleconference melalui zoom kadang terkendala sinyal yang tidak lancar. 
p-ISSN : 2599-1418

e-ISSN : 2599-1426

Berdasarkan pemaparan masalah di atas, maka yang menjadi tujuan dalam penelitian ini adalah 1) Persepsi guru terhadap proses pembelajaran daring di SMP Negeri 1 Sawan ditinjau dari kognitif. 2) Persepsi guru terhadap proses pembelajaran daring di SMP Negeri 1 Sawan ditinjau dari afektif. 3) Persepsi guru

\section{METODE}

Jenis penelitian ini yaitu penelitian deskriptif. Penelitian deskriptif adalah penelitian yang menggambarkan atau menganalisis suatu hasil penelitian tetapi tidak digunakan untuk membuat kesimpulan (Sugiyono, 2017). Penelitian deskriptif dilakukan untuk mendeskripsikan persepsi guru terhadap proses pembelajaran daring pada masa (pandemi covid-19) yang berlokasi di SMP Negeri 1 Sawan, Desa Sawan Kecamatan Sawan, Kabupaten Buleleng, Bali.

Populasi dan sampel dalam penelitian ini adalah seluruh guru yang mengajar di SMP Negeri 1 Sawan yang berjumlah 54 orang guru. Penelitian ini menggunakan tipe penelitian deskriptif dengan pendekatan kualitatif, dimana dalam penelitian ini data yang diperoleh dalam bentuk tulisan dan juga angka yang dianalisis kemudian dipaparkan, digambarkan dan disesuaikan dengan kenyataan di lapangan, dan selanjutnya dapat dijadikan dasar dalam penarikan kesimpulan. Berdasarkan sumber yang
Jurnal Pendidikan Ekonomi Undiksha

Vol. 13 No. 2 (2021)

terhadap proses pembelajaran daring di SMP Negeri 1 Sawan ditinjau dari konatif.

Berdasarkan dari uraian latar belakang di atas, maka dalam penelitian ini penulis tertarik untuk mengangkat judul tentang: "Persepsi Guru Terhadap Proses Pembelajaran Daring Pada Masa (Pandemi Covid-19) di SMP Negeri 1 Sawan".

dimiliki, penelitian ini menggunakan data primer dan data sekunder. Adapun sumber data dalam penelitian ini yaitu 1) Data Primer, Data primer ini diperoleh secara langsung oleh peneliti dari sumbernya tanpa perantara pihak lain (Sugiyono, 2017). Peneliti menggunakan sumber data primer berupa kuesioner dan hasil wawancara sehingga dapat diperoleh jawaban secara langsung dari masing-masing responden. 2) Data Sekunder, Data sekunder adalah data yang diperoleh dalam bentuk yang sudah jadi berupa publikasi. Data sekunder dalam penelitian ini adalah jumlah guru yang mengajar di SMP Negeri 1 Sawan.

Persepsi guru terhadap proses pembelajaran daring. Dimensi persepsi guru yang diukur dalam penelitian ini, yaitu (a) kognitif, (b) afektif, dan (c) konatif, untuk kepentingan pengumpulan data di lapangan, maka variabel penelitian dijabarkan ke dalam indikator-indikator. Secara rinci variabel, dimensi, indikator dan instrumen yang digunakan yaitu sebagai berikut.

Tabel 3.1

Operasional Variabel Penelitian

\begin{tabular}{|c|c|c|}
\hline Dimensi & Definisi & Indikator \\
\hline $\begin{array}{l}\text { Kognitif } \\
\text { (Pengetahua }\end{array}$ & $\begin{array}{l}\text { Respons kognitif terkait dengan } \\
\text { pengetahuan, keterampilan, dan } \\
\text { informasi seseorang mengenai } \\
\text { sesuatu. Respons tersebut } \\
\text { timbul apabila adanya perubahan } \\
\text { terhadap apa yang dipahami } \\
\text { atau dipersepsikan oleh } \\
\text { khalayak. }\end{array}$ & $\begin{array}{l}\text { a. pengetahuan tentang penerapan } \\
\text { pembelajaran daring } \\
\text { b. pemahaman mengenai tahapan } \\
\text { pembelajaran daring } \\
\text { c. pemahaman mengenai proses } \\
\begin{array}{l}\text { penggunaan pembelajaran } \\
\text { daring serta pengaplikasiannya }\end{array}\end{array}$ \\
\hline Afek & $\begin{array}{l}\text { Respons afektif berhubungan } \\
\text { dengan sikap, dan penilaian } \\
\text { seseorang terhadap sesuatu. Hal } \\
\text { tersebut timbul apabila ada } \\
\text { perubahan pada apa yang } \\
\text { disenangi khalayak terhadap } \\
\text { sesuatu. }\end{array}$ & $\begin{array}{ll}\text { a. } & \begin{array}{l}\text { Penilaian terhadap kebijakan } \\
\text { penggunaan pembelajaran }\end{array} \\
\text { daring } & \\
\text { b. } & \text { Keyakinan bahwa dengan } \\
\text { penggunaan pembelajaran } \\
\text { daring akan efektif bagi siswa dan } \\
\text { guru }\end{array}$ \\
\hline
\end{tabular}




\begin{tabular}{|c|c|c|}
\hline Dimensi & Definisi & Indikator \\
\hline & & $\begin{array}{l}\text { c. Penilaian terhadap penggunaan } \\
\text { pembelajaran daring }\end{array}$ \\
\hline $\begin{array}{l}\text { Konatif } \\
\text { (Tindakan) }\end{array}$ & $\begin{array}{l}\text { Respons konatif berhubungan } \\
\text { dengan perilaku nyata atau } \\
\text { tindakan seseorang yang } \\
\text { meliputi tindakan kegiatan, atau } \\
\text { kebiasaan berperilaku. Respons } \\
\text { tersebut menunjukkan intensitas } \\
\text { sikap yaitu kecenderungan } \\
\text { bertindak atau berperilaku } \\
\text { seseorang terhadap objek sikap }\end{array}$ & $\begin{array}{l}\text { a. Keinginan untuk melakukan } \\
\text { inovasi dalam memberikan materi } \\
\text { secara daring kepada siswa } \\
\text { b. Keinginan untuk selalu } \\
\text { profesional dalam memberikan } \\
\text { pembelajaran daring kepada } \\
\text { siswa }\end{array}$ \\
\hline
\end{tabular}

Untuk jumlah soal dalam kuesioner yaitu sebagai berikut.

\begin{tabular}{lcc}
\hline \multicolumn{1}{c}{ Dimensi } & Nomor Soal & Jumlah Butir Soal \\
\hline Kognitif & $1,2,3,4,5,6,7,8$ & 8 \\
Afektif & $9,10,11,12,13,14,15,16$ & 8 \\
Konatif & $17,18,19,20,21,22,23,24$ & 8 \\
\hline \multicolumn{1}{r}{ Total } & $\mathbf{2 4}$ & $\mathbf{2 4}$ \\
\hline
\end{tabular}

Instrumen penelitian ini berupa kuesioner untuk memperoleh data-data kualitatif yaitu persepsi guru terhadap sistem pembelajaran daring. Seluruh variabel akan diukur dengan menggunakan skala likert. Menurut Sugiyono, 2017 "skala likert digunakan untuk mengukur sikap, pendapat, dan persepsi seseorang atau sekelompok orang tentang fenomena sosial". Untuk keperluan analisis maka jawaban kuesioner diberi skor penilaian yaitu a) Jika jawaban Sangat Baik diberi skor 5. b) Jika jawaban Baik diberi skor 4. c) Jika jawaban Cukup Baik diberi skor 3. d) Jika jawaban Tidak Baik diberi skor 2. e) Jika jawaban Sangat Tidak Baik diberi skor 1. Kuesioner sebagai alat pengumpulan data ordinal yang merupakan penjabaran dari indikator variabel. Sebelum digunakan untuk pengumpulan data di lapangan, terlebih dahulu harus diuji tingkat validitas dan reliabilitasnya. Untuk menguji tingkat

Tabel. 3.2

Skor Tertinggi dan Terendah Persepsi Guru Terhadap Proses Pembelajaran Daring

\begin{tabular}{cccc}
\hline No & Dimensi & Skor Tertinggi & Skor Terendah \\
\hline 1 & Kognitif & 2.160 & 432 \\
2 & Afektif & 2.160 & 432 \\
3 & Konatif & 2.160 & 432 \\
\hline
\end{tabular}




\begin{tabular}{|c|c|c|}
\hline \multicolumn{2}{|c|}{ Total } & 1.296 \\
\hline \multicolumn{3}{|c|}{$\begin{array}{c}\text { Tabel } 3.3 \\
\text { Interval untuk Persepsi Guru Terhadap Proses Pembelajaran Daring }\end{array}$} \\
\hline No & Dimensi & Interval \\
\hline 1 & Kognitif & 345 \\
\hline 2 & Afektif & 345 \\
\hline 3 & Konatif & 345 \\
\hline \multicolumn{2}{|c|}{ Total } & 1.035 \\
\hline
\end{tabular}

Tabel 3.4

Kriteria Total Skor Variabel Persepsi Guru Terhadap Proses Pembelajaran Daring Ditinjau Dari Dimensi Kognitif

\begin{tabular}{cc}
\hline Rentang Skor & Kategori \\
\hline $1.825-2.160$ & Sangat Baik \\
$1.479-1.824$ & Baik \\
$1.133-1.478$ & Cukup Baik \\
$787-1.132$ & Tidak Baik \\
$432-786$ & Sangat Tidak Baik \\
\hline
\end{tabular}

Tabel 3.5

Kriteria Total Skor Variabel Persepsi Guru Terhadap Proses Pembelajaran Daring Ditinjau Dari Dimensi Afektif

\begin{tabular}{cc}
\hline Rentang Skor & Kategori \\
\hline $1.825-2.160$ & Sangat Baik \\
$1.479-1.824$ & Baik \\
$1.133-1.478$ & Cukup Baik \\
$787-1.132$ & Tidak Baik \\
$432-786$ & Sangat Tidak Baik \\
\hline
\end{tabular}

Tabel 3.5

Kriteria Total Skor Variabel Persepsi Guru Terhadap Proses Pembelajaran Daring Ditinjau Dari Dimensi Afektif

\begin{tabular}{cc}
\hline Rentang Skor & Kategori \\
\hline $1.825-2.160$ & Sangat Baik \\
$1.479-1.824$ & Baik \\
$1.133-1.478$ & Cukup Baik \\
$787-1.132$ & Tidak Baik \\
$432-786$ & Sangat Tidak Baik \\
\hline
\end{tabular}

Tabel 3.6

Kriteria Total Skor Variabel Persepsi Guru Terhadap Proses Pembelajaran Daring Ditinjau Dari Dimensi Konatif

\begin{tabular}{cc}
\hline Rentang Skor & Kategori \\
\hline $1.825-2.160$ & Sangat Baik \\
$1.479-1.824$ & Baik \\
$1.133-1.478$ & Cukup Baik \\
$787-1.132$ & Tidak Baik \\
$432-786$ & Sangat Tidak Baik \\
\hline
\end{tabular}


p-ISSN : 2599-1418

e-ISSN : 2599-1426
Jurnal Pendidikan Ekonomi Undiksha

Vol. 13 No. 2 (2021)
HASIL DAN PEMBAHASAN

Untuk hasil dan pembahasan dalam penelitian ini yaitu sesuai dari tujuan penelitian dimana untuk mengetahui persepsi guru di SMP Negeri 1 Sawan di tinjau dari 3 aspek yaitu aspek kognitif, aspek afektif, dan aspek konatif. Hasil penelitian ini yaitu sebagai berikut.

Persepsi guru terhadap proses pembelajaran daring pada masa (pandemi covid-19) di SMP Negeri 1 Sawan yang ditinjau dari aspek kognitif.

Tabel 4.1

Persepsi Guru Terhadap Proses Pembelajaran Daring Pada Masa (Pandemi Covid-19) di SMP Negeri 1 Sawan Ditinjau Dari Segi Kognitif

\begin{tabular}{llll}
\hline Dimensi & Skor & Rentang Skor & Kategori \\
Kognitif & 1.665 & $1.479-1.824$ & Baik \\
Total & $\mathbf{1 . 6 6 5}$ & $\mathbf{1 . 4 7 9 - 1 . 8 2 4}$ & Baik \\
\hline
\end{tabular}

Berdasarkan hasil data pada tabel 4.1 maka dapat dijelaskan bahwa dimensi kognitif memperoleh skor sebesar 1.665 yang berada pada rentang skor 1.479 1.824, sehingga dapat dikategorikan baik. Hal ini berarti persepsi guru dalam segi pengetahuan terhadap proses pembelajaran daring kategori baik, mulai dari tata cara penggunaan pembelajaran daring hingga pelaksanaannya dilapangan.

Persepsi guru terhadap proses pembelajaran daring pada masa (pandemi covid-19) di SMP Negeri 1 Sawan ditinjau dari segi afektif menunjukkan hasil seperti yang terdapat pada tabel 4.2 .

Tabel 4.2

Persepsi Guru Terhadap Proses Pembelajaran Daring Pada Masa (Pandemi Covid-19) di SMP Negeri 1 Sawan Ditinjau Dari Segi Afektif

\begin{tabular}{llll}
\hline Dimensi & Skor & Rentang Skor & Kategori \\
Afektif & 1.699 & $1.479-1.824$ & Baik \\
Total & $\mathbf{1 . 6 9 9}$ & $\mathbf{1 . 4 7 9 - \mathbf { 1 . 8 2 4 }}$ & Baik \\
\hline
\end{tabular}

Berdasarkan hasil analisis data pada tabel 4.2 maka dapat dijelaskan bahwa pada dimensi afektif mendapat skor sebesar 1.699 yang berada pada rentang skor 1.479 - 1.824, sehingga dapat dikategorikan baik. Hal tersebut menunjukkan bahwa sikap para guru terkait proses pembelajaran daring bersikap positif.

Persepsi guru terhadap proses pembelajaran daring pada masa (pandemi covid-19) di SMP Negeri 1 Sawan ditinjau dari segi konatif menunjukkan hasil seperti yang terdapat pada tabel 4.3.

Tabel 4.3

Persepsi Guru Terhadap Proses Pembelajaran Daring Pada Masa (Pandemi Covid-19) di SMP Negeri 1 Sawan Ditinjau Dari Segi Konatif

\begin{tabular}{llll}
\hline Dimensi & Skor & Rentang Skor & Kategori \\
Konatif & 1.784 & $1.479-1.824$ & Baik \\
Total & $\mathbf{1 . 7 8 4}$ & $\mathbf{1 . 4 7 9 - 1 . 8 2 4}$ & Baik \\
\hline
\end{tabular}


p-ISSN : 2599-1418

e-ISSN : 2599-1426

Berdasarkan hasil analisis data pada tabel 4.3 maka dapat dijelaskan bahwa pada dimensi konatif mendapat skor sebesar 1.784 yang berada pada rentang skor 1.479 - 1.824, sehingga dapat dikategorikan baik. Hal tersebut menunjukkan bahwa persepsi guru terkait tindakan atau penerapan kegiatan dalam proses pembelajaran daring para guru cenderung melaksanakan pembelajaran daring dengan baik.

\section{PEMBAHASAN}

Persepsi guru terhadap proses pembelajaran daring pada masa (pandemi covid-19) ditinjau dari dimensi kognitif secara umum persepsi guru sudah berada dalam tingkatan positif. Dalam proses pengumpulan data berlangsung peneliti juga melakukan sesi wawancara terhadap beberapa guru terkait persepsi guru terhadap proses pembelajaran daring dari segi kognitif, diantaranya yaitu wawancara terhadap ibu Ni Luh Muji, S.Pd menurut beliau penggunaan pembelajaran daring ini awalnya memang sulit terutama bagi guru yang umurnya lebih tua, namun perlahan rata-rata guru sudah bisa menggunakan dengan baik. Ibu Nyoman Maha Utami, S.Pd juga menambahkan bahwa menurut beliau penggunaan pembelajaran daring harus menuntut para guru lebih kreatif dan melek akan ilmu pengetahuan teknologi, yang awalnya tidak semua guru bisa melakukan namun secara perlahan sudah berjalan hampir sekeluruhan. Sejalan dengan pendapat yang diberikan oleh ibu Ni Made Warni, S.Pd juga menambahkan bahwa pengetahuan para guru terhadap pembelajaran daring di masa pandemi covid-19 semakin bertambah, guru mendapatkan banyak pengalaman dari adanya pembelajaran daring ini kemudian para guru sekarang mulai terampil dan melek akan teknologi dalam pelaksanaan pembelajaran daring, itu artinya dalam segi kognitif persepsi guru terhadap proses pembelajaran daring sudah kategori baik, hanya saja apa yang masih kurang perlunya peningkatan kualitas agar semakin baik.

Selanjutnya, persepsi guru terhadap proses pembelajaran daring pada masa pandemi (covid-19) ditinjau dari dimensi afektif secara umum persepsi guru dalam segi afektif sudah berada dalam tingkatan
Jurnal Pendidikan Ekonomi Undiksha

Vol. 13 No. 2 (2021)

positif. Para guru menilai bahwa kebijakan pemerintah mengenai pembelajaran daring adalah solusi alternatif di tengah pandemi covid-19. Pada masa pandemi ini diterapkannya pembelajaran daring merupakan sebuah tantangan dalam mengajar, guru harus menyesuaikan dengan keadaan yang terjadi saat ini walau apa yang para guru usahakan dalam penyampaian materi daring tidak seluruhnya bisa terserap oleh siswa, namun para guru selalu berusaha meningkatkan kualitas pembelajaran dan memperbaiki kekurangan yang ada. Peneliti juga melakukan wawancara kepada beberapa narasumber, salah satunya yaitu ibu Ni Luh Putu Gita Septiarini, S.Pd yang menuturkan bahwa menurut beliau pembelajaran daring ini merupakan sebuah tantangan bagi beberapa guru yang memang terkendala akan teknologi dimana guru tersebut memang dalam kondisi umur yang terbilang lumayan senior, namun dengan kerja keras dan komitmen bersama-sama semua itu perlahan mulai menjadi suatu kebiasaan yang membawa dampak positif bagi semua. Menurut bapak Nyoman Danayasa, S.Pd beliau menambahkan di awal di terapkannya pembelajaran daring ini memang sangatlah menjadi beban bagi guru-guru karena tidak semua guru terbiasa mengajar menggunakan akses internet meskipun demikian seiring berjalannya waktu dengan kegigihan, ketekunan, dan semangat para guru sekarang membuat semuanya berjalan sesuai dengan kebijakan pemerintah, walau masih ada kendala dan kekurangan yang dimana kedepan akan terus menjadi evaluasi dan perbaikan. Selaras dengan pendapat tersebut ibu Ketut Nusantari, S.Pd beliau menambahkan bahwa para guru masih terus melakukan perbaikan-perbaikan dari kekurangan yang ada. Sebagai seorang guru harus memikirkan berbagai solusi dalam mengatasi kekurangan tersebut. Kendala-kendala yang dihadapi menjadi tantangan bagi guru untuk menciptakan suasana belajar daring yang lebih baik. Secara keseluruhan persepsi guru terkait proses pembelajaran daring dari segi afektif sudahlah baik, hanya saja hal yang menjadi kekurangan harus terus dievaluasi agar semakin baik untuk kedepannya. 
p-ISSN : 2599-1418

e-ISSN : 2599-1426

Berikutnya, persepsi guru terhadap proses pembelajaran daring pada masa pandemi (covid-19) ditinjau dari dimensi konatif secara umum persepsi guru dalam segi konatif sudah berada dalam tingkatan positif. Hal tersebut menunjukkan bahwa persepsi guru terkait tindakan atau penerapan kegiatan dalam proses pembelajaran daring para guru cenderung melaksanakan pembelajaran daring dengan baik. Para guru memiliki pandangan yang baik terkait bagaimana pembelajaran daring itu harus dilakukan, menurut beberapa guru segala kendala haruslah menjadi tanggung jawab yang harus dipecahkan dan sikap profesional guru harus menjadi yang utama. Peneliti juga melakukan wawancara kepada beberapa narasumber, salah satunya yaitu ibu Ni Komang Sri Yuli Windari Natih, S.Pd menurut beliau dalam tindakan pembelajaran daring haruslah tetap teguh kepada sikap profesional guru, karena dengan demikian menjadikan proses belajar lebih baik. Kemudian peneliti melakukan wawancara dengan bapak Supriyadi, S.Pd beliau menambahkan bahwa proses pembelajaran daring menuntut para guru untuk melakukan bermacam-macam media pembelajaran daring yang variatif sehingga peserta didik bisa keluar dari zona kebosanan mereka. Diupayakan menggunakan media daring yang biasa untuk interaktif. Menggunakan media daring yang bisa live misalnya zoom meeting, google meet, dan lain-lain agar karakter atau perilaku para murid relatif terpantau, untuk mengakses media daring tersebut diperlukan sinyal yang baik, jika sinyal tidak baik maka media belajar yang ditampilkan tidak dapat terlihat. Selaras dengan pendapat ibu Ni Made Mena Satriani, S.Pd menurut beliau menggunakan media daring yang dominan live dapat memantau perilaku peserta didik selama mengikuti kegiatan penilaian. Akan lebih baik apabila pada pembelajaran dan penilaian melibatkan orang tua/wali murid bisa membantu mengawasinya dengan baik di rumah masing-masing. Selanjutnya guru bisa lebih sering memberikan tugas praktikum yang dibuat oleh siswa melalui video dan dikirim ke WhatsApp. Dengan hal tersebut dapat menumbuhkan semangat siswa untuk mengikuti pembelajaran. Selaras dengan
Jurnal Pendidikan Ekonomi Undiksha

Vol. 13 No. 2 (2021)

pendapat tersebut ibu Nyoman Sriyani, S.Pd menurut beliau dengan pembelajaran daring para guru tidak hanya memberikan materi namun juga guru berusaha menampilkan dan memberikan contoh teladan kepada para siswa, seperti tepat waktu dan memenuhi kewajiban sebagai seorang pendidik. Maka dari itu guru harus saling bahu-membahu satu sama lain diantara para guru di SMP Negeri 1 Sawan untuk menciptakan suasana belajar daring yang baik. Dengan demikian persepsi guru terkait proses pembelajaran daring ditinjau dari segi konatif sudah kategori baik, terlihat dari cara pandang guru yang positif, hanya saja apa yang masih kurang perlunya peningkatan kualitas agar semakin baik.

Berdasarkan hasil penelitian yang telah dilakukan, persepsi guru terhadap proses pembelajaran daring pada masa (pandemi covid-19) di SMP Negeri 1 Sawan yang ditinjau dari 3 (tiga) aspek yaitu kognitif, afektif, dan konatif sudah masuk ke dalam kategori positif. Para guru menilai proses pembelajaran daring memang merupakan sebuah tantangan, banyak kendala-kendala yang dihadapi para guru, terlebih di awal mulai berlakunya aturan pembelajaran daring dan juga menjadi kendala bagi guruguru yang umurnya sudah memasuki masa tua, karena tidak semua para guru melek akan teknologi, dengan semangat dan rasa tanggung jawab para guru sangat antusias dan berusaha menjadikan kendala-kendala tersebut menjadi sebuah tantangan. Penggunaan teknologi pembelajaran daring yang semakin kreatif dan maju tentu akan sangat bermanfaat dan dapat memudahkan bagi guru dan siswa pada masa pandemi sekarang ini dalam meningkatkan kualitas pembelajaran yaitu sesuai dengan teori yang dikemukakan oleh (Jogiyanto, 2007) yang menyatakan bahwa persepsi tentang kemudahan penggunaan sebuah teknologi akan mampu meningkatkan kinerja mereka. Persepsi kemudahan adalah kepercayaan seseorang terhadap suatu teknologi akan berdampak positif pada peningkatan kinerjanya bila berguna bagi pengguna teknologi tersebut. Dengan demikian proses pembelajaran daring akan semakin membawa dampak positif terlebih kondisi pandemi covid-19 sekarang ini. 
p-ISSN : 2599-1418

e-ISSN : 2599-1426

Pandangan para guru terkait proses pembelajaran daring yaitu sudah baik, namun terdapat beberapa kendala yang masih sulit dipecahkan terkait teknis sesuai dengan pandangan (Soekartiwi, 2015) yaitu sebagai berikut (1) kurangnya interaksi antar tenaga pendidik dan peserta didik atau bahkan antar peserta didik itu sendiri. Kurangnya interaksi ini bisa memperlambat terbentuknya values dalam proses pembelajaran; (2) kecenderungan mengabaikan aspek psikomotorik atau aspek sosial dan sebaliknya mendorong aspek komersial; (3) proses pembelajarannya cenderung ke arah pelatihan dari pada pendidikan; (4) siswa yang tidak memiliki motivasi belajar yang tinggi akan cenderung bermalas-malasan dan gagal; (5) tidak semua tempat tersedia fasilitas internet dan jaringan. Kondisi dilapangan lebih kepada masalah sinyal saat melakukan pembelajaran daring, terkadang tidak semua berjalan lancar, jika sinyal tidak baik maka media belajar yang ditampilkan tidak dapat terlihat oleh siswa yang sinyalnya bermasalah, dengan demikian guru harus memikirkan alternatif untuk masalah tersebut. Guru dituntut sebaik mungkin dalam menyampakain materi belajar dalam kondisi daring agar apa yang disampaikan mudah ditangkap oleh siswa, maka dari guru harus kreatif dalam membuat media pembelajaran daring. Hal tersebut menunjukkan bahwa pelaksanaan proses pembelajaran daring ini juga mendapat respons baik oleh para guru di SMP Negeri 1 Sawan, terlihat usaha keras guru untuk meningkatkan pemahaman, kompetensi guru dan memberikan yang terbaik kepada siswa, para guru bersamasama sudah memahami tentang pembelajaran daring baik dari aspek kognitif, afektif, dan konatif, walau masih ada beberapa kendala yang perlu diperbaiki untuk proses pembelajaran yang lebih baik

\section{SIMPULAN DAN SARAN}

Berdasarkan hasil analisis data dan pembahasan yang telah dipaparkan sebelumnya, maka peneliti dapat menarik kesimpulan yaitu 1) Persepsi guru terhadap proses pembelajaran daring pada masa (pandemi covid-19) di SMP Negeri 1 Sawan yang ditinjau dari aspek kognitif memperoleh
Jurnal Pendidikan Ekonomi Undiksha

Vol. 13 No. 2 (2021)

skor sebesar 1.665 yang berada pada rentang skor $1.479-1.824$, sehingga dapat dikategorikan baik. 2) Persepsi guru terhadap proses pembelajaran daring pada masa (pandemi covid-19) di SMP Negeri 1 Sawan yang ditinjau dari aspek afektif mendapat skor sebesar 1.699 yang berada pada rentang skor $1.479-1.824$, sehingga dapat dikategorikan baik. 3) Persepsi guru terhadap proses pembelajaran daring pada masa (pandemi covid-19) di SMP Negeri 1 Sawan yang ditinjau dari aspek konatif mendapat skor sebesar 1.784 yang berada pada rentang skor $1.479-1.824$, sehingga dapat dikategorikan baik.

Bagi sekolah terus melakukan evaluasi, motivasi, dan semangat kepada para guru dan juga lebih memfasilitasi guru dalam melakukan pembelajaran daring seperti masa pandemi sekarang ini.

Bagi guru agar lebih mengembangkan lagi pembelajaran yang dapat membuat kondisi belajar tetap efektif walaupun dilakukan dalam jaringan, seperti lebih sering melakukan komunikasi kepada peserta didik, penyampaian yang mudah agar dapat dipahami oleh peserta didik. Guru lebih meningkatkan kreativitasnya sebagai pendidik untuk menjadi guru yang lebih profesional.

Bagi pemerintah agar memperhatikan masalah-masalah teknis yang terjadi pada saat proses pembelajaran daring, dari masalah tersebut agar dicarikan solusi terbaik demi memudahkan proses pembelajaran dimasa pandemi covid-19 sekarang ini.

Peserta didik lebih diberikan motivasi dalam belajar agar pada saat pelaksanaan belajar melalui jaringan peserta didik tetap memiliki semangat yang tinggi dan dapat mengikuti proses pembelajaran dengan baik sesuai dengan tujuan pembelajaran yang akan dicapai.

Bagi peneliti lain penelitian ini disarankan lebih dikembangkan lagi, karena di dalam penelitian ini hanya meneliti persepsi guru, sehingga untuk peneliti selanjutnya dapat menambah objek penelitian misalnya dengan membandingkan persepsi guru dan siswa ataupun orang tua siswa. 


\section{DAFTAR PUSTAKA}

Ahmadi, A. (2016). Evaluasi Pelaksanaan ELearning Pada Proses Pembelajaran Sistem Kelistrikan Siswa Kelas X Jurusan Teknik Otomotif di SMK N 2 Pengasih. Fakultas Teknik Universitas Negeri Yogyakarta.

Anggianita, S. (2020). Persepsi Guru Terhadap Proses Pembelajaran Daring di Sekolah Dasar Negeri 013 Kumantan. Universitas Pahlawan Tuanku Tambusai.

Bimo, W. (2010). Psikologi Umum. ANDI.

Dewi, W. A. F. (2020). Dampak COVID-19 terhadap Implementasi Pembelajaran Daring di Sekolah Dasar. EDUKATIF: JURNAL ILMU P ENDIDIKAN. https://doi.org/10.31004/edukatif.v2i1.89.

Dhaifi, I. (2020). Studi Analisis Dampak Pademi Covid-19 Terhadap Eksistensi Pembelajaran Pendidikan Agama Islam di Indonesia. Edupedia. https://doi.org/10.35316/edupedia.v5i1.880

Firman, F., \& Rahayu, S. (2020). Pembelajaran Online di Tengah Pandemi Covid-19. Indonesian Journal of Educational Science (IJES).

https://doi.org/10.31605/ijes.v2i2.659.

Handayani, D. (2020). Penyakit Virus Corona 2019. Jurnal Respirologi Indonesia.

Hasibuan, A., Syahputra, Z., \& ... (2020). Pengembangan Sistem Pembelajaran Online di Masa Pandemi Covid-19 Berbasis Open Source. Journal of Computer .

Irianto, A. (2004). Statistik Konsep Dasar dan Aplikasinya. Prenada Media.

Jogiyanto, H. (2007). Sistem Informasi Keperilakuan. CV Andi Offset.

Kementerian Pendidikan dan Kebudayaan Republik Indonesia. (2020). Surat Edaran Menteri Pendidikan Dan Kebudayaan Republik Indonesia Nomor 35952/MPK.A/HK/2020.

Kemendikbud. (2013). Permendikbud No 109 tentang Penyelenggaraan Pendidikan Jarak Jauh pada Pendidikan Tinggi. Jakarta: Kementerian Pendidikan dan Kebudayaan.

Kinasih, S., \& Sinaga, K. (2020). Kajian Penerapan Teori Pembelajaran Bermakna Ausubel Berdasarkan Perspektif Alkitabiah Pada Materi Hidrokarbon [A Study On The Application Of Ausubel's Meaningful Learning Theory On Hydrocarbon Chemical Learning Based On A Biblical Perspective]. Polyglot: Jurnal Ilmiah. https://doi.org/10.19166/pji.v16i2.2128.

Kiptiah, M. (2015). Respons Kognitif, Afektif dan Konatif Pegawai Fakultas Sayriah dan
Hukum Syarif Hidayatullah Jakarta Terhadap Minat Berasuransi Syariah. Universitas Islam Negeri Jakarta.

Maskar, S., Dewi, P. S., \& Puspaningtyas, N. D. (2020). Online Learning \& Blended Learning: Perbandingan Hasil Belajar Metode Daring Penuh dan Terpadu. PRISMA.

https://doi.org/10.35194/jp.v9i2.1070.

Megawanti, P., Megawati, E., \& Nurkhafifah, S. (2020). Persepsi Peserta Didik terhadap PJJ pada Masa Pandemi COVID-19. Jurnal IImiah Pendidikan.

Mursalin, Sulaiman, \& Nurmasyitah. (2017). Peran Guru Dalam Pelaksanaan Manajemen Kelas di Gugus Bungong Seulangakecamatan Syiah Kualakota Banda Aceh. Jurnal IImiah Pendidikan Guru Sekolah Dasar.

Mustakim. (2020). Efektivitas Pembelajaran Daring Menggunakan Media Online Selama Pandemi Covid-19 Pada Mata Pelajaran Matematika the Effectiveness of E-Learning Using Online Media During the Covid-19 Pandemic in Mathematics. Al Asma: Journal of Islamic Education.

Pamungkas, R. V. (2020). Pengaruh E-Learning Berbasis Web terhadap minat belajar anak sekolah dasar. Prosiding Konferensi IImiah Dasar.

Riyanda, A. R., Herlina, K., Wicaksono, B. A., \& Lampung, B. (2020). Evaluasi Implementasi Sistem Pembelajaran Daring. Jurnal IKRA-ITH Humaniora.

Rusman, dkk. (2011). Pembelajaran Berbasis Teknologi Informasi dan Komunikasi, Mengembangkan Profesionalitas Guru. Raja Grafindo Persada.

Setiawan, L. D. (2020). Pendidikan Indonesia Di Tengah Pandemi Covid-19. Prosiding Seminar Bahasa Dan Sastra Indonesia (Senasbasa).

Soekartiwi. (2015). Merancang dan Menyelenggarakan E-learning. Ardana Media.

Sugiyono. (2017). Metode Penelitian Pendidikan: Pendekatan Kuantitatif, Kualitatif, dan R\&D. Alfabeta.

Wood, J. T. (2013). Komunikasi: Teori dan Praktik (Komunikasi Dalam Kehidupan Kita). Selemba Empat. 